\title{
Gillnetting for small indigenous cyprinids in a Sri Lankan reservoir where culture-based fisheries are practiced
}

\author{
D. Ananda Athukorala ${ }^{1}$ and Upali S. Amarasinghe ${ }^{2 *}$ \\ ${ }^{1}$ Inland Aquatic Resources and Aquaculture Division, National Aquatic Resources Research \\ and Development Agency, Crow Island, Colombo 15, Sri Lanka
}

${ }^{2}$ Department of Zoology and Environmental Management, University of Kelaniya, Kelaniya, Sri Lanka

*Corresponding author (zoousa@kln.ac.lk)

https://orcid.org/0000-0002-0465-6950

Received: 23.04.2020 Revised: 30.08.2020 Accepted: 04.09.2020 Published online: 15.09.2020

\begin{abstract}
In Sri Lankan reservoirs, small, indigenous fish species (SIS) are abundant and can be differentially exploited using small mesh (15-38 mm stretched mesh sizes) gillnets without any detrimental effects on the cichlid fisheries. However, in the recent past a paradigm shift in the reservoir fisheries of Sri Lanka is observed from total dependence on exotic cichlids to exploitation of exotic carps, stocked in reservoirs for the development of culture-based fisheries (CBF). As fingerlings of Chinese and Indian major carps and common carp are regularly stocked in reservoirs for the development of CBF, it is essential to investigate the potential impact of the use of small mesh gillnets to catch SIS on stocked fish fingerlings on CBF. In the present study, small mesh gillnets were used to exploit SIS during September 2011 to March 2013 when carp fingerlings were stocked in Chandrika wewa, Sri Lanka. The results revealed that no carp fingerlings (except 2 specimens of Indian carp species) were caught in any of the fishing trials with small mesh gillnets. As juvenile fish and stocked fish fingerlings occur in shallow littoral areas of reservoir, and as small mesh gillnets are laid at the depths $\geq 1.5 \mathrm{~m}$, there is a habitat segregation of these two categories of fish. It is therefore possible to introduce a subsidiary fishery with small mesh gillnets to exploit SIS, which can co-exist with CBF in reservoirs of Sri Lanka.
\end{abstract}

Keywords: reservoir fisheries; small indigenous species; Cyprinidae; Cichlidae; culture-based fisheries

\section{INTRODUCTION}

Inland fish and fisheries are crucial for many socially, economically and nutritionally vulnerable groups of people around the world because of their vital role in providing an important source of animal protein and essential micronutrients for local communities, especially in the developing world and ensuring global food security (Yong et al. 2014; Funge-Smith and Bennett 2019). In the tropical belt, reservoirs make a significant contribution to inland fish production (Fernando and Holčik 1991; Welcomme 2001). However, reservoir fish production in many counties of Asia is dependent on a few species so that utilization of spectrum of biological production in reservoir ecosystems is often not fully realized (Pet et al. 1996; Amarasinghe and De Silva 2015). Occurrence of small indigenous fish species (SIS) in inland waters of many tropical countries are reported
(De Silva and Sirisena 1987, 1989; Ahmed et al. 2001; Amarasinghe et al. 2016; Kolding et al. 2019). Nevertheless, many of these fishery resources remain unexploited or underexploited and this may be due to, among other reasons, the fisheries management strategies currently in place targeting the exotic fish species which contribute most to commercial fisheries production by regulating mesh sizes of gillnets (Amarasinghe and De Silva 2015).

Previous studies in Sri Lankan reservoirs have shown that SIS could be differentially exploited using gillnets of stretched mesh sizes, $15 \mathrm{~mm}$ to $38 \mathrm{~mm}$ without adverse effects on the fishery based on larger fish species such as exotic cichlid species (i.e., Oreochromis mossambicus and $O$. niloticus), which account for over $70 \%$ of the landings (Amarasinghe 1985, 1990; De Silva and Sirisena 1989; Pet and Piet 1993). Such differential exploitation of SIS and commercially 


\section{Aananda Athukorala and Upali S. Amarasinghe}

important fish species is possible since individuals of the latter group exhibit depth preference, juveniles occupying shallow littoral areas while adults inhabit deeper areas of the reservoir. In deeper areas of reservoirs $(\geq 1.5 \mathrm{~m}$ depth), gillnet selection curves of effective mesh sizes for the two groups of fish do not overlap (Ajith Kumara et al. 2009a). In Sri Lankan reservoirs, abundant SIS are reported to be Amblypharyngodon melettinus, Dawkinsia singhala, Puntius chola and P. dorsalis (De Silva and Sirisena 1987; Amarasinghe 1990; Pet and Piet 1993; Ajith Kumara et al. 2009b). SIS are recognized as a group of fish rich in minerals and vitamin A, having high potential for contributing to improved food and nutrition security, income and livelihoods of the people of South and Southeast Asia (Roos et al, 2007; Thilsted 2012; Fielder et al. 2016). Amarasinghe et al. (2016) recommended introducing a subsidiary smallmesh gillnet fishery for exploiting SIS in Sri Lankan reservoirs to enhance inland fisheries production in the country.

Culture-based fisheries (CBF) development in the multitude of reservoirs is a recent trend in the Sri Lankan inland fishery (Wijenayake et al. 2005; Amarasinghe and Nguyen 2009; Amarasinghe and Wijenayake 2015; Pushpalatha and Chandrasoma 2010). In CBF, hatcheryreared fingerlings are released to reservoirs for subsequent capture after a reasonable growth period. As shape characteristics of stocked fish fingerlings are more or less similar to those of SIS, particularly A. melettinus, one can argue that the use of small-mesh gillnets for exploiting SIS may pose a potential risk of stocked fingerlings being caught jeopardizing CBF efforts. Depending on the hypothesis that juvenile stages of fish occupy littoral zones and adults move to deeper areas of reservoirs, and that exploitation of SIS using small mesh gillnets would not make stocked fingerlings vulnerable for getting caught, the present study was carried out to find the answer to the question if there would be any adverse impact on the CBF development strategies if a subsidiary small-mesh gillnet fishery is introduced to exploit SIS. Experimental fishing with small-mesh gillnets was carried out in a reservoir for the purpose, during the period of stocking of fingerlings of Indian major carps for CBF production, and this paper aims at providing answer to the research question mentioned above.

\section{MATERIALS AND METHODS}

The present study was carried out in Chandrika wewa (area: 439 ha; Location: $6^{\circ} 19^{\prime} \mathrm{N} ; 80^{\circ} 51^{\prime}$ E; Figure 1), an irrigation reservoir Sri Lanka.

This reservoir was selected due to the reasons that it is a medium-sized perennial reservoir with a fishing community of manageable size operating only 12 fishing boats, that fishers were cooperative for conducting experimental fishing, and that National Aquaculture Development Authority of Sri Lanka (NAQDA) has chosen this reservoir for stocking fish fingerlings for CBF development. Based on the information about annual fish stocking plan of NAQDA, the present study was conducted from September 2011 to March 2013, coinciding the duration of stocking of carp fingerlings in Chandrika wewa.

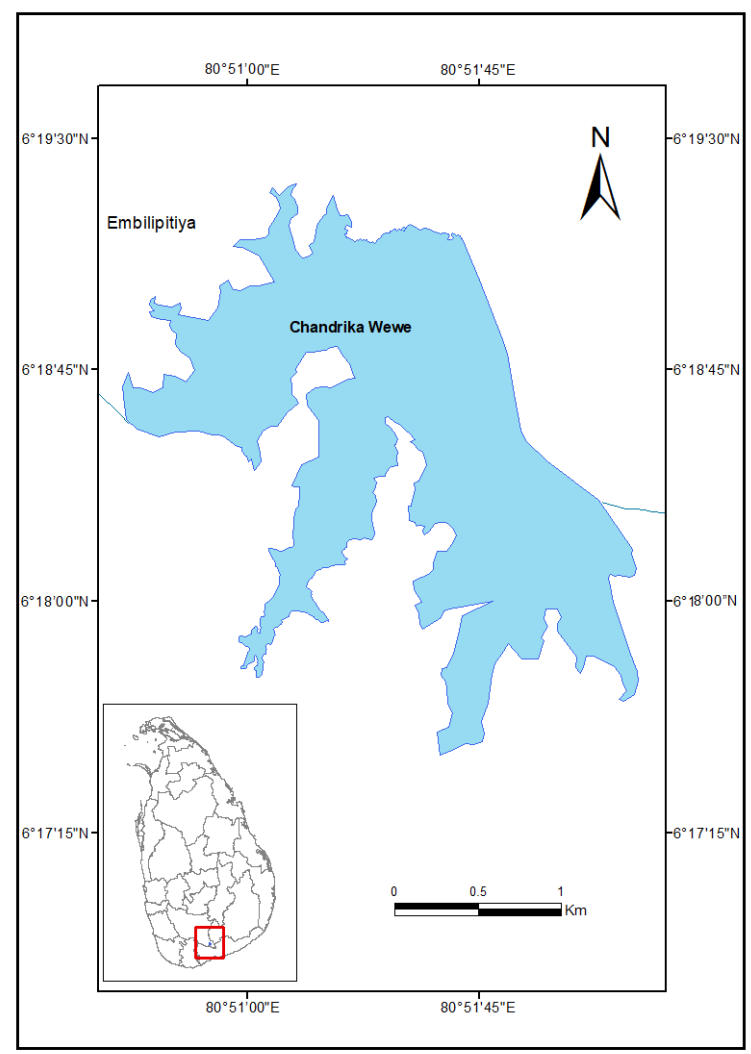

Figure 1 Map of Chandrika wewa.

Authors approached office bearers of the fishermen's society and based on their advice, two reliable fishermen, who were willing to record daily catches of small-mesh gillnets, were chosen to get assistance for experimental gillnet fishing. Gillnet pieces of 7 different mesh sizes were used for two experimental fishing trial periods; during September 2011 to May 2012 (Trial period I) and during June 2012 to March 


\section{Aananda Athukorala and Upali S. Amarasinghe}

2013 (Trial period II). During the two trial periods, two different heights of gillnets were used while keeping other dimensions and filament characteristics unchanged. The details of dimensions and filament characteristics, and calendar of experimental fishing trials during Trial periods I and II are given in Table 1.

Table 1 Dimensions and filament characteristics of experimental gillnets

\begin{tabular}{|c|c|c|c|c|c|c|c|}
\hline \multirow{2}{*}{ Characteristics } & \multicolumn{7}{|c|}{ Net code } \\
\hline & GN1 & GN2 & GN3 & GN4 & GN5 & GN6 & GN7 \\
\hline \multicolumn{8}{|c|}{ Trial period I (from September 2011 to May 2012) } \\
\hline Mesh size (stretched) (mm) & 10 & 12 & 15 & 19 & 25 & 32 & 38 \\
\hline Hanging ratio* & 0.5 & 0.5 & 0.5 & 0.5 & 0.5 & 0.5 & 0.5 \\
\hline Filament thickness & 2 ply & 2 ply & 2 ply & 2 ply & 2 ply & 2 ply & 2 ply \\
\hline \multicolumn{8}{|l|}{ Height of net (m) } \\
\hline Trial period I & 3.8 & 4.6 & 4.8 & 5.5 & 6.9 & 7.3 & 8.2 \\
\hline Trial period II & - & - & - & 2.7 & 3.4 & 2.3 & 5.5 \\
\hline \multicolumn{8}{|l|}{ Length of net $(\mathrm{m})$} \\
\hline Trial period I & 23.8 & 25.6 & 28.3 & 16.5 & 17.4 & 23.8 & 26.5 \\
\hline Trial period II & - & - & - & 16.5 & 17.4 & 23.8 & 26.5 \\
\hline $\begin{array}{l}\text { Trial date (fishing } \\
\text { occasion) }\end{array}$ & \multicolumn{7}{|c|}{ Number of fishing trials } \\
\hline 15-16 Sep 2011 (I) & 2 & 4 & - & - & - & - & - \\
\hline 28-30 Sep 2011 (II) & 1 & 10 & 9 & - & - & - & - \\
\hline 19-21 Oct 2011 (III) & 3 & 10 & 7 & - & - & - & - \\
\hline 2-4 Nov 2011 (IV) & - & 9 & 9 & - & - & - & - \\
\hline 16-17 Feb 2012 (V) & 3 & 3 & 3 & 3 & 3 & 3 & 3 \\
\hline 21-23 Mar 2012 (VI) & - & 3 & 3 & 3 & 3 & 3 & 3 \\
\hline 25 Apr 2012 (VII) & - & 1 & 1 & 1 & 1 & 1 & 1 \\
\hline 16 May 2012 (VIII) & - & - & - & 1 & 1 & 1 & 1 \\
\hline 19-20 Jun 2012 (IX) & - & - & - & 2 & 2 & 2 & 2 \\
\hline 28 Feb-01 Mar 2013 (X) & - & - & - & - & - & 6 & 8 \\
\hline
\end{tabular}

The two fishermen who were selected for seeking assistance for experimental fishing were given one gillnet piece each of the 7 mesh sizes. The fishermen were requested to catch fish on mutually convenient dates when the first author (D.A.A.) could visit and supervise fishing activities. During the study period, there were 10 experimental fishing occasions, and on these fishing occasions 135 experimental fishing trials were carried out using gillnets of 7 mesh sizes (Table 1). Fishermen have laid gillnets in the deeper areas $(\geq 1.5 \mathrm{~m}$ depth) of the reservoir in the late afternoon and recovered nets with gilled/entangled fishes on the following morning. As the lowest height of gillnet $(10 \mathrm{~mm}$ mesh gillnet during trial period II; Table 1) was $1.9 \mathrm{~m}$, fishermen were compelled to set their gillnets at least at the reservoir depth of $2 \mathrm{~m}$. The fishermen were provided with $\log$-sheets to record meshwise and species group-wise catches. As an incentive, the two fishermen who were engaged in experimental fishing were requested to sell their catches enabling them to supplement their fisheries income.

The following information was obtained from NAQDA.

1. Stocking size of fingerlings;

2. Species-wise stocked numbers from January 2011 to December 2014;

3. Monthly species-wise fish production from January 2011 to December 2014

The monthly catches of SIS in experimental gillnets were determined from the data recorded in the fishermen's log-sheets for the trial periods I and II separately. Analysis of gillnet catches of SIS for each trial period separately was necessary due to the differences in dimensions of gillnets (i.e., depth of net) of each mesh size between the trial seasons. Monthly mesh-wise and species group-wise catch data were expressed as $\mathrm{kg}$ per month and were plotted to compare with commercial fisheries landings. For this purpose, monthly species group-wise stocking data and 
monthly species group-wise fish production data obtained from the NAQDA database were also used to prepare histograms. The commercial gillnet mesh sizes in the fishery of Chandrika wewa ranged from $6.9 \mathrm{~cm}$ to $35.6 \mathrm{~cm}$, and the different mesh gillnets are used by fishermen targeting various fish species in the fish community (Table 2). Fishermen lay their nets late in the afternoon and recover following day morning. The fishing depth of commercial gillnetting is $>3 \mathrm{~m}$.

Table 2 Mesh sizes of commercial gillnets in the fishery of Chandrika wewa and species targeted by each mesh size.

\begin{tabular}{ll}
\hline Gillnet mesh size $(\mathrm{cm})$ & Target species \\
\hline 6.9 & Oreochromis mossambicus \\
7.6 & O. niloticus \\
8.4 & \\
8.9 & O. mossambicus, O. niloticus, \\
\hline 10.2 & Cirrhinus mrigala, Cyprinus carpio, Labeo rohita \\
11.4 & Cirrhinus mrigala, Cyprinus carpio, Labeo rohita \\
12.7 & \\
\hline 14.0 & Catla catla \\
15.2 & \\
21.0 & \\
25.4 & \\
35.6 & \\
\hline
\end{tabular}

\section{RESULTS}

List of fish species caught in the experimental gillnets during the study period and the mean body length (and range) of each species are given in Table 3.

Table 3 List of fish species caught in the experimental gillnets during the study period and the mean body lengths (and ranges) of each species caught in small mesh gillnets. Abb. - Abbreviations as given in Figure 3.

\begin{tabular}{llrr}
\hline Species & Abb. & $\begin{array}{r}\text { Mean length (TL in } \\
\mathrm{cm})\end{array}$ & $\begin{array}{r}\text { Length range }(\mathrm{TL} \text { in } \\
\mathrm{cm})\end{array}$ \\
\hline Amblypharyngodon melettinus & $\mathrm{Am}$ & 6.0 & $3.0-9.0$ \\
Cirrihinus mrigala (2 specimens) & $\mathrm{Cm}$ & 15.3 & $14.5-16.0$ \\
Dawkinsia singhala & $\mathrm{Ds}$ & 10.8 & $7.5-14.5$ \\
Glossogobius giuris* & $\mathrm{Gg}$ & 7.4 & $3.0-35.0$ \\
Hyporhamphus quoyi (=gaimardi) & $\mathrm{Hg}$ & 9.9 & $6.5-13.0$ \\
Labeo dussumieri* & $\mathrm{Ld}$ & 17.0 & $13.0-22.0$ \\
Mystus keletius & $\mathrm{Mk}$ & 12.1 & $9.0-14.0$ \\
Puntius chola & $\mathrm{Pc}$ & 11.5 & $7.0-17.5$ \\
Puntius dorsalis* & $\mathrm{Pd}$ & 10.9 & $10.0-12.5$ \\
Rasbora daniconius & $\mathrm{Rd}$ & 6.5 & $4.5-9.5$ \\
Others* & $\mathrm{Ot}$ & & \\
$\quad$ Etroplus suratensis & & 8.1 & $7.0-10.5$ \\
$\quad$ Garra ceylonensis & & 19.0 & $18.0-20.0$ \\
$\quad$ Heteropneustes fossilis & & 14.1 & $12.5-14.5$ \\
$\quad$ Ompok bimaculatus & & 20.0 & - \\
$\quad$ (1 specimen) & & & \\
$\quad$ Systomus sarana & & $20.9(\mathrm{TL})$ & \\
\hline$*$ caught in 25-38 mm mesh & &
\end{tabular}

* caught in 25-38 mm mesh gillnets during Trial II 
Of these, A. melettinus was the most dominant species. The size range of fish fingerlings stocked was $5-7 \mathrm{~cm}$, which was presumably vulnerable to $15-18 \mathrm{~mm}$ mesh gillnets. The gillnets of $12 \mathrm{~mm}$ mesh size were not recommended because previous studies (Amarasinghe 1985) indicated that immature individuals of A. melettinus were caught in this mesh size. Interestingly however, none of the stocked fish fingerlings, except in one occasion when two specimens of fingerlings of Cirrihinus mrigala was caught in a $19 \mathrm{~mm}$ mesh gillnet in May 2012, were caught experimental gillnets. Stocked species, and species caught in the commercial landings are given in Table 4.

Table 4 List of species stocked in Chandrika wewa during the study period (Source: NAQDA) and species caught in the commercial gillnets

\begin{tabular}{l}
\hline Species stocked \\
\hline Exotic carps \\
Catla catla \\
Cirrhinus mrigala \\
Cyprinus carpio \\
Ctenopharyngodon idella \\
Labeo rohita \\
Cichlids \\
Oreochromis niloticus \\
Others \\
Labeo dussumieri \\
Macrobrachium rosenbergii \\
Species caught from naturally recruited populations \\
Channa striata \\
Etroplus suratensis \\
Glossogobius giuris \\
Ompok bimaculatus \\
Systomus sarana \\
\hline
\end{tabular}

Mesh-wise experimental gillnet catches of major SIS in Chandrika wewa during the study period (Figure 2) indicate that there are speciesspecific mesh sizes for different SIS and that for the most abundant SIS, A. melettinus, the effective gillnet mesh sizes are $15 \mathrm{~mm}$ and 19 $\mathrm{mm}$. Species composition of SIS caught in the 10 fishing occasions (Figure 3) indicates that except in one fishing occasion ( $8^{\text {th }}$ fishing occasion in May 2012) when 2 specimens of $C$. mrigala were caught, none of the stocked fingerlings was caught in small-mesh gillnets.

Number of fishes of three categories stocked in different months from January 2011 to December 2014 (Figure 4(A)) coincided the experimental gillnet fishing trials for SIS in Chandrika wewa. Monthly fish production of three categories of fishes (Figure 4(B)) indicates that stocking of fish fingerlings had a significant positive impact on CBF harvest. It must be noted that as stocking of fish fingerlings had been carried out during preceding years, such stocking has also influenced species composition of the landings.

\section{DISCUSSION}

Since early 1980s, several studies have been reported providing scientific evidence that subsidiary gillnet fishery for SIS, which can coexist with the tilapia gillnet fishery would be feasible in major reservoirs of Sri Lanka (Amarasinghe 1985, 1990; De Silva and Sirisena 1987, 1989; Pet and Piet 1993; Ajith Kumara et al. 2009a). Exploitation of SIS in reservoirs of Sri Lanka does not take place, which may be due to, among other reasons, current gillnet mesh regulations ( $\geq 8.5 \mathrm{~cm}$ stretched mesh size) prevent the use of gillnets of smaller mesh sizes (Amarasinghe and De Silva 2015). Despite these regulatory constraints for exploiting SIS, in some reservoirs of Sri Lanka, fishermen are engaged in small mesh gillnet fisheries to exploit SIS, providing supplementary income for fishing 
communities (Amarasinghe et al. 2009, 2016). Furthermore, in terms of trophic interactions in reservoir fish communities, exploitation of SIS is shown to be advantageous to enhance existing commercial-scale fisheries mainly dependent on exotic cichlids, through reduction of competition for food resources (Pet et al. 1996; Amarasinghe et al. 2014).

Present study has shown that in Chandrika wewa, exploitation of SIS and stocking of carp fingerlings for $\mathrm{CBF}$ development can be accomplished simultaneously because stocked fingerlings are not vulnerable to be getting caught in small mesh (15-38 mm stretched mesh size) gillnets. As regular stocking of fingerlings of exotic carps for CBF development in reservoirs is a recent development in Sri Lanka, these findings are crucial for introducing small mesh gillnet fisheries along with stocking of fish fingerlings. As juvenile stages of fish species in lentic ecosystems such as lakes and reservoirs are known to occur in littoral zones (Levin et al. 2004; Ríha et al. 2015), depth preference of juvenile carp species stocked in the reservoir occur in the littoral zone. As such, small mesh gillnets laid in deeper areas ( $\geq 1.5 \mathrm{~m}$ depth) of the reservoir to catch SIS do not impact carp fingerlings stocked in the reservoir. Amarasinghe et al. (2016) also demonstrated that small-mesh (15-52 mm stretched mesh) gillnets can be used to exploit SIS in the deeper, pelagic areas of Sri Lankan reservoirs, without impacting on the recruitment of cichlids and without a potential danger of 'growth overfishing' of cichlid stocks. Present study therefore confirms the hypothesis that exploitation of SIS using small mesh gillnets would not make stocked fingerlings vulnerable for getting caught.

Amarasinghe et al. (2002) have demonstrated that SIS in Sri Lankan reservoirs have high production per biomass $(\mathrm{P} / \mathrm{B})$ ratios compared to those which are exploited by the commercial reservoir fisheries. The species having high $\mathrm{P} / \mathrm{B}$ ratios (i.e., high turnover rates) are known to be able to withstand heavy fishing pressure. As such, SIS in reservoirs can be expected to support productive fisheries as suggested by Amarasinghe et al. (2002).

Regulatory restrictions hampering exploitation of hitherto unexploited SIS fishery resources are not unique to Sri Lanka. Such situations are also reported to exist in reservoirs of Indian sub-continent (Kumar 2010; Sugunan 2010). There is also ample evidence that SIS occur in high abundance in reservoirs in several Asian countries (Ahmed et al. 2001; Jutagate et al. 2003; Roos et al. 2007) and Ethiopian lakes in Africa (Vijverberg et al. 2012). Also, regular stocking of fish fingerlings for CBF development is not uncommon in the Asian region (Kartamihardja 2015; Saphakdy et al. 2009; Nguyen et al. 2005; Srun and De Silva 2015). As such, findings of the present study have a regional applicability. In conclusion, it is reiterated that introduction of a subsidiary fishery for SIS in reservoirs in Sri Lanka is desirable to enhance inland fisheries production. There are legal provisions to issue licenses to identifiable group of fishermen under the Fisheries and Aquatic Resources (Amendment) Act No. 35 of 2013 (Anon. 2013). 

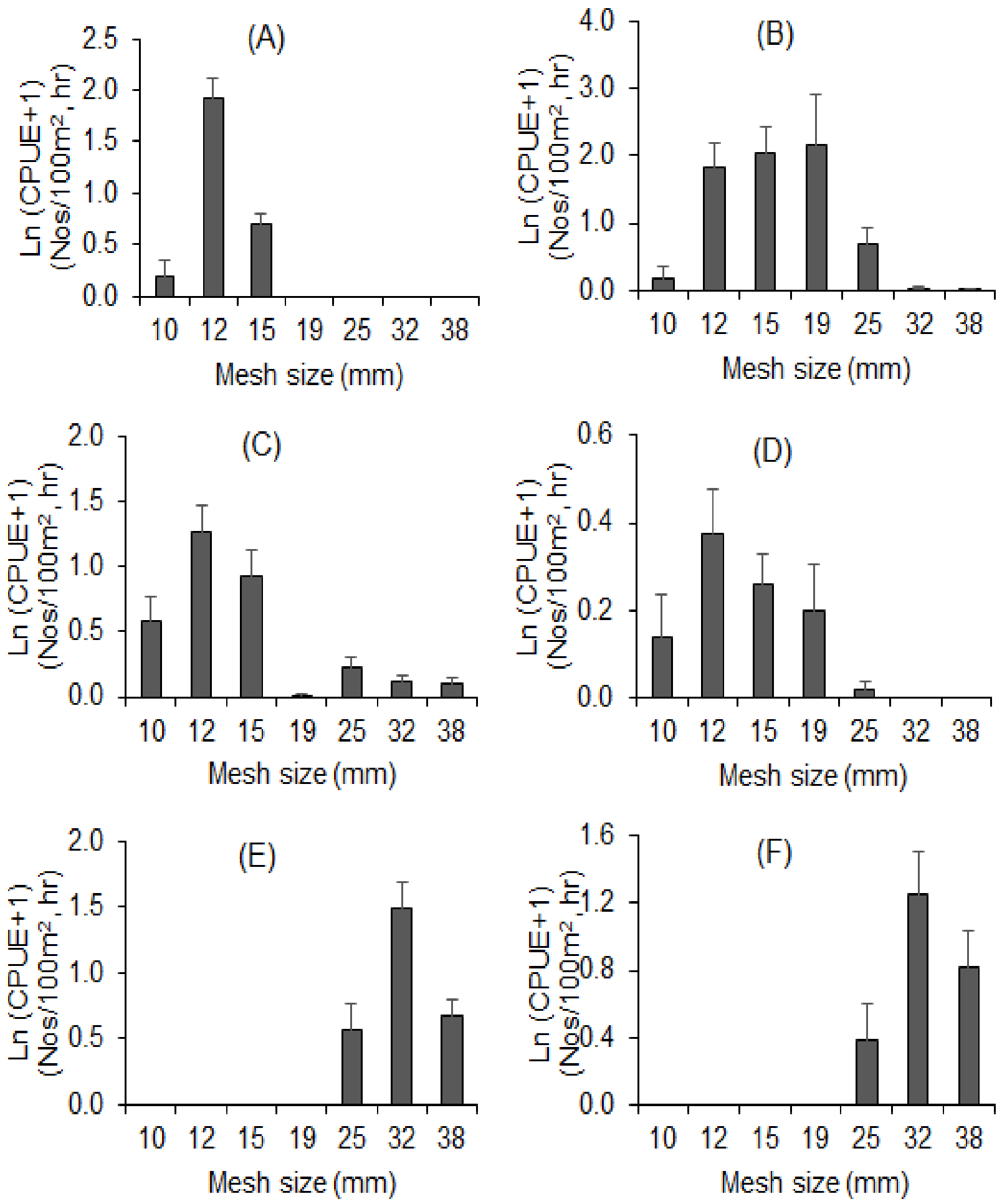

Figure 2 Relative abundance of major SIS caught in different mesh gillnets during the study period, showing effectiveness of various mesh sizes for catching individual SIS in Chandrika wewa. (A) $H$. gaimardi; (B) A. melettinus; (C) Glossogobius giuris; (D) Rasbora daniconius; (E) Dawkinsia singhala 


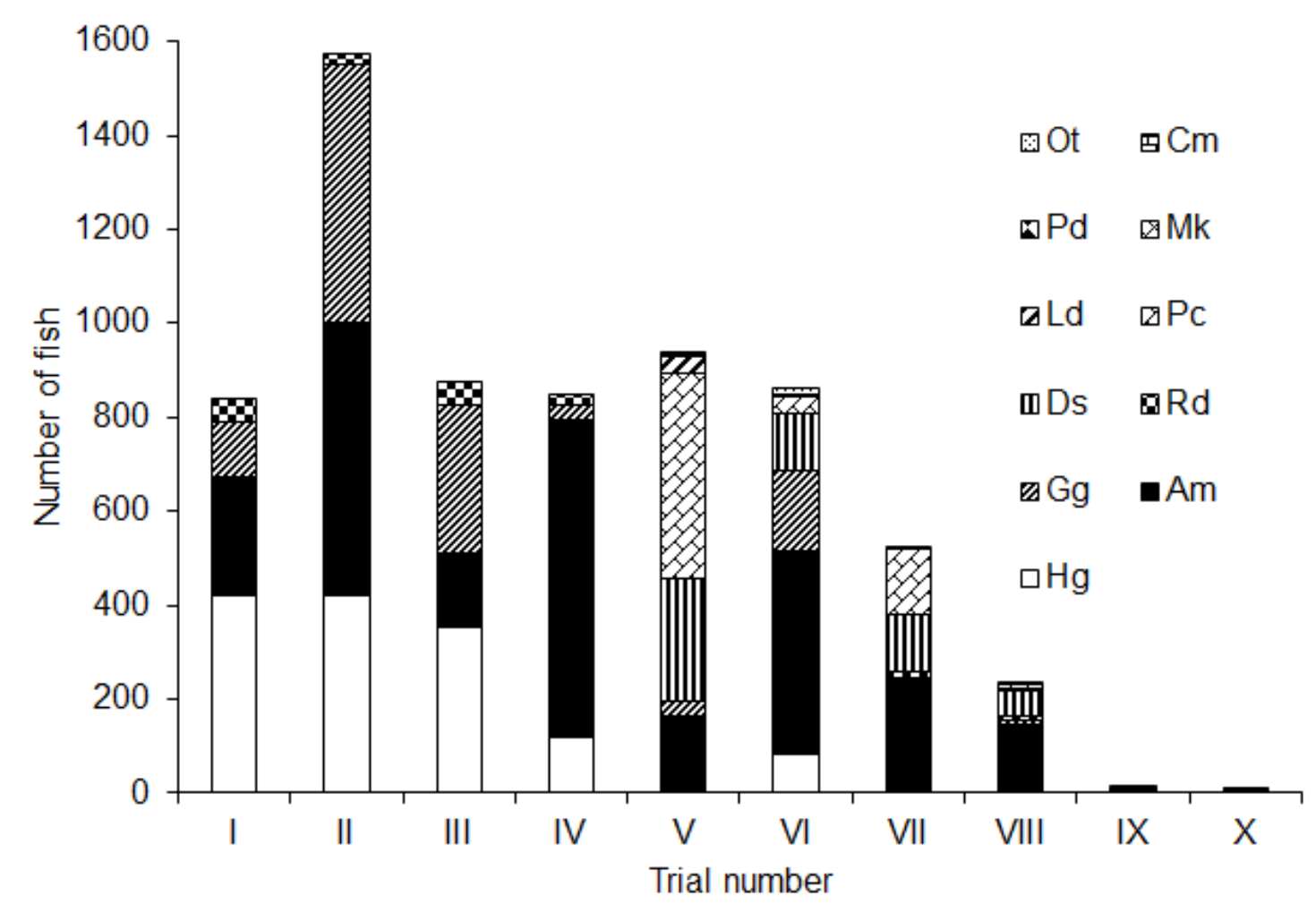

Figure 3 Species composition of SIS caught in small-mesh experimental gillnets during 10 fishing occasions. Fishing occasions are as given in Table 1. Abbreviations of species names are as given in Table 2. Note: In the $8^{\text {th }}$ fishing occasion, only 2 specimens of stocked $C$. mrigala were caught. 

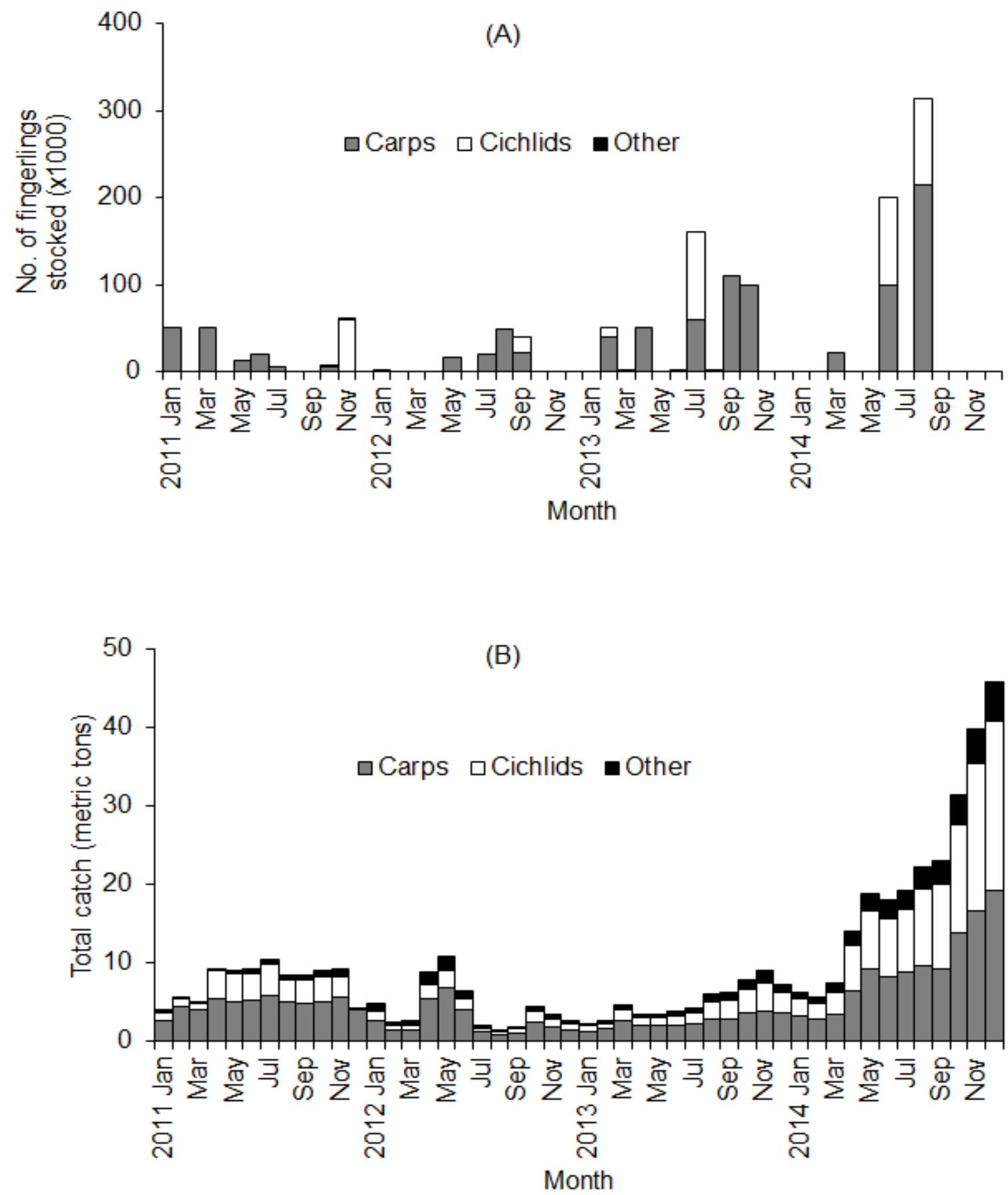

Figure 4 Fish species stocked and total landings during January 2011 - December 2014 in Chandrika wewa. List of three categories of species stocked and those which were caught in commercial fisheries are given in Table 3 (Source of data: NAQDA)

\section{ACKNOWLEDGEMENTS}

We are thankful to National Aquatic Resources Research and Development Agency (NARA) for providing facilities to carry out this study. Our thanks are also due to fishermen in Chandrika wewa for their assistance in experimental gillnet fishing.

\section{REFERENCES}

Ahmed, K.K.U., J.B. Hambrey \& Z. Rahaman. 2001. Trends in interannual yield variation of reservoir fisheries in Bangladesh, with special reference to Indian major carps. Lakes and Reservoirs: Research and Management 6: 8594. doi:10.1046/j.1440-1770.2001.00134.x. 


\section{Aananda Athukorala and Upali S. Amarasinghe}

Ajith Kumara, P.A.D., U.S. Amarasinghe, F. Schiemer, G. Winkler \& M. Schabuss. 2009a. Gillnet selectivity of small cyprinids in three Sri Lankan reservoirs. Asian Fisheries Science 22: 885-900.

Ajith Kumara, P.A.D., U.S. Amarasinghe, F. Schiemer, G. Winkler \& M. Schabuss. 2009b. Distribution and abundance of unexploited fish species in three Sri Lankan reservoirs. Asian Fisheries Science 22: 845-862.

Amarasinghe, U. S. \& S.S. De Silva. 2015. Fishes and fisheries of Asian inland lacustrine waters. In: J.F. Craig (Ed.) Freshwater Fisheries Ecology, pp. 384-403. Chichester, UK: Wiley-Blackwell. doi: 10.1002/9781118394380.ch31

Amarasinghe, U.S. 1985. Studies on the exploitation of minor cyprinids in Parakrama Samudra, a man-made lake in Sri Lanka, using gillnets. Journal of National Aquatic Resources Agency (Sri Lanka) 32: 11-23.

Amarasinghe, U.S. 1990. Minor cyprinid resources in a man-made lake in Sri Lanka: a potential supplementary source of income for fishermen. Fisheries Research 9: 81-89. doi:10.1016/0165-7836(90)90043-U.

Amarasinghe, U.S., P.A.D. Ajith Kumara \& M.H.S. Ariyaratne. 2002. Role of nonexploited fishery resources in Sri Lankan reservoirs as a source of food for cage aquaculture. In: Management and Ecology of Lake and Reservoir Fisheries (Ed. I.G. Cowx). Fishing News Books, Blackwell Science, Oxford, U.K., 332-343 pp.

Amarasinghe, U.S. \& T.T.T. Nguyen. 2009. Enhancing rural farmer income through fish production: Secondary use of water resources in Sri Lanka and elsewhere. In: S.S. De Silva and F.B. Davy (Eds.) Success stories in Asian aquaculture, pp. 103-130. Springer Science, Netherlands. ISBN 978-90-481-3085-6 (Print) ISBN 978-90-481-3087-0 (Online).

Amarasinghe, U.S., J. Vijverberg, W.S. Weliange \& M. Vos. 2014. Food web patterns and diversity in tropical fish communities. Lakes and Reservoirs: Research and Management. 19: 56-69. DOI: $10.1111 / \mathrm{lre} .12060$

Amarasinghe, U.S., D.E.M. Weerakoon \& D.A. Athukorala. 2009. Emerging boost in Sri Lankan reservoir fish production: a case of adoption of past research findings. Aquaculture Asia 14(1): 26-28.

Amarasinghe, U.S. \& W.M.H.K. Wijenayake. 2015. Results of a decade of $\mathrm{R}$ and $\mathrm{D}$ efforts on culture-based fisheries in Sri Lanka. In: S.
S. De Silva, B. A. Ingram, and S.Wilkinson (Eds.), Perspectives on culture based fisheries development in Asia, pp. 59-71. Network of Aquaculture Centres in Asia-Pacific, Bangkok, Thailand.

Amarasinghe, U.S., P.A.D. Ajith Kumara \& S.S De Silva. 2016. A rationale for introducing a subsidiary fishery in tropical reservoirs and lakes to augment inland fish production: case study from Sri Lanka supplemented with evidence from elsewhere. Food Security 8: 769-781. DOI: 10.1007/s12571-016-0596-4

Anon. 2013. Fisheries and Aquatic Resources (Amendment) Act, No. 35 of 2013 (27 p). Colombo: Parliament of the Democratic Socialist Republic of Sri Lanka.

De Silva, S.S. \& H.K.G. Sirisena. 1987. New fish resources of reservoirs in Sri Lanka: feasibility of introduction of a subsidiary gillnet fishery for minor cyprinids. Fisheries Research 6: 17-34. doi:10.1016/01657836(87)90004-X.

De Silva, S.S. \& H.K.G. Sirisena. 1989. New fish resources of reservoirs in Sri Lanka: 3. Results of commercial-scale trials and yield estimates of a gillnet fishery for minor cyprinids. Fisheries Research 7: 279-287. doi:10.1016/0165-7836(89)90061-1.

Fernando, C.H. \& J. Holčik. 1991. Fish in reservoirs. Internationale Revue der gesamten Hydrobiologie und Hydrographie 76: 149167.

https://doi.org/10.1002/iroh.19910760202

Fielder, J. L., K. Lividin, E. Drummond \& S.H. Thilsted. 2016. Strengthening the contribution of aquaculture to food and nutrition security: the potential of a vitamin A-rich, small fish in Bangladesh. Aquaculture 452: 291-303. https://doi.org/10.1016/j.aquaculture.2015.11. 004

Funge-Smith, S. \& A. Bennett. 2019. A fresh look at inland fisheries and their role in food security and livelihoods. Fish and Fisheries 20: 1176-1195. https://doi.org/10.1111/faf.12403

Jutagate, T., S.S. De Silva \& N.S. Mattson. 2003. Yield, growth and mortality rate of the Thai river sprat, Clupeichthys aesarnensis, in Sirinthorn reservoir, Thailand. Fisheries Management and Ecology 10: 221-231. doi:10.1046/j.1365-2400.2003.00338.x.

Kartamihardja, E.S. 2015. Potential of culturebased fisheries in Indonesian inland waters. In: S.S. De Silva, B.A. Ingram \& S. Wilkinson (Eds.), Perspectives on culture- 


\section{Aananda Athukorala and Upali S. Amarasinghe}

based fisheries developments and stock enhancements in Asia, pp. 73-81. Bangkok: Network of Aquaculture Centres in AsiaPacific.

Kolding, J., P. van Zwieten, F. Marttin, S. FungeSmith \& F. Poulain. 2019. Freshwater small pelagic fish and fisheries in major African lakes and reservoirs in relation to food security and nutrition. FAO Fisheries and Aquaculture Technical Paper No. 642. Rome, FAO. 124 pp.

Kumar, K.G. (Ed.). 2010. Small Indigenous Freshwater Fish Species: Their Role in Poverty Alleviation, Food Security and Conservation of Biodiversity. Proceedings of a workshop, February 2010, L.S. Chennai, India: Graphic Print.

Levin, W.-C., N. Okun \& T. Mehner. 2004. Determinants of the distribution of juvenile fish in the littoral area of a shallow lake. Freshwater Biology 49(4): 410-424. https://doi.org/10.1111/j.1365-

2427.2004.01193.x

Nguyen, H. S., A.T. Bui, D.Q. Nguyen, D.Q. Truong, L.T. Le, N.W. Abery \& S.S. De Silva. 2005. Culture-based fisheries in small reservoirs in northern Vietnam: effect of stocking density and species combinations. Aquaculture Research 36: 1037-1048. https://doi.org/10.1111/j.13652109.2005.01312.x

Pet, J.S. \& G.J. Piet. 1993). The consequences of habitat occupation and habitat overlap of the introduced tilapia Oreochromis mossambicus and indigenous fish species for fishery management in a Sri Lankan reservoir. Journal of Fish Biology 43 (Suppl. A): 193 208. doi:10.1111/j.1095-8649.1993.tb01187.x

Pet, J.S., G.J.M. Gevers, W.L.T. Van Densen \& J. Vijverberg. 1996. Management options for a more complete utilization of the biological fish production in Sri Lankan reservoirs. Ecology of Freshwater Fish 5: 1-14. https://doi.org/10.1111/j.16000633.1996.tb00032.x

Pushpalatha, K.B.C. \& J. Chandrasoma. 2010. Culture-based fisheries in minor perennial reservoirs in Sri Lanka: Variability in production, stocked species and yield implications: Technical note. Journal of Applied Ichthyology 26(1): 98-103. https://doi.org/10.1111/j.14390426.2009.01361.x

Ř́ha, M., D. Ricard, M. Vašek, et al. 2015. Patterns in diel habitat use of fish covering the littoral and pelagic zones in a reservoir. Hydrobiologia 747: 111-131. https://doi.org/10.1007/s10750-014-2124-x

Roos, N., Md. A. Wahab, M.A.R. Hossain \& S.H. Thilsted. 2007. Linking human nutrition and fisheries: Incorporating micronutrientdense, small indigenous fish species in carp polyculture production in Bangladesh. Food Nutrition Bulletin 28(2) (Suppl.): S280-S293.

Saphakdy, B., A. Phomsouvanh, B. Davy, T.T.T. Nguyen \& S.S. De Silva. 2009. Contrasting community management and revenue sharing practices of culture-based fisheries in Lao PDR. Aquaculture Asia Magazine XIV 3: 26.

Sparre, P \& S.C. Venema. 1998. Introduction to tropical fish stock assessment. Part 1. Manual. FAO Fisheries Technical Paper No. 306.1: Rev. 2. FAO, Rome.

Srun, L. S. \& S. S. De Silva. 2015. Challenges and constraints for developing $\mathrm{CBF}$ in Cambodia and a possible strategy for success. In: S. S. De Silva, B. A. Ingram \& S. Wilkinson (Eds.), Perspectives on culturebased fisheries development in Asia, pp. 1725. Bangkok: Network of Aquaculture Centres in Asia-Pacific.

Sugunan, V.V. 2010. Inland fisheries resource enhancement and conservation in India. In: Miao, W., S. De Silva \& B. Davy (Eds), Inland Fisheries Resource Enhancement and Conservation in Asia, pp. 39-60. RAP Publication 2010/22, Bangkok: FAO Regional Office.

Thilsted, S.H. 2012. The potential of nutrient-rich small fish species in aquaculture to improve human nutrition and health. In: R.P. Subasinghe, J.R. Arthur, D.M. Bartley, S.S. De Silva, M. Halwart, N. Hishamunda, C.V. Mohan \& P. Sorgeloos, (Eds.), Farming the Waters for People and Food, pp. 57-73. Proceedings of the Global Conference on Aquaculture 2010, Phuket, Thailand. 22-25 September 2010. Rome: FAO and Bangkok: NACA

Vijverberg, J., E. Dejen, A. Getahun, A.J. Leopold \& L.A.J. Nagelkerke. 2012. The composition of fish communities of nine Ethiopian lakes along a north-south gradient: threats and possible solutions. Animal Biology 62: 315-335. doi:10.1163/157075611X618246.

Welcomme, R.L. 2001. Inland fisheries: ecology and management. Oxford: Fishing News Books, Blackwell Science. 
Wijenayake, W.M.H.K., U.A.D. Jayasinghe, U.S. $\quad$ https://doi.org/10.1111/j.1365-

Amarasinghe, J.A. Athula, K.B.C. 2400.2005.00447.x

Pushpalatha \& S.S. De Silva. 2005. Culture- Youn, S-J., W.W. Taylor, A.J. Lynch, I.G. Cowx, based fisheries in non-perennial reservoirs in T.D. Beard, D. Bartley \& F. Wu. 2014. Inland Sri Lanka: production and relative capture fishery contributions to global food performance of stocked species. Fisheries security and treats to their future. Global Food Management and Ecology 12: 249-258. Security 3: 142-148. doi:10.1016/j.gfs.2014 .09 .005 